\title{
ANALYSIS OF SAFETY SYSTEM RELIABILITY KI HADJAR DEWANTARA MAKO KODICLATAL BUILDING TOWARDS FIRE HAZARDS PREVENTION
}

\author{
Dodiek Alfianzi ${ }^{1}$, Ikhwan Syahtaria ${ }^{2}$, Udisubakti C.M ${ }^{3}$, I Made Jiwa Astika ${ }^{4}$ \\ 1,2,4Indonesian Naval Technology College, Bumimoro-Morokrembangan, Surabaya 60187, Indonesia \\ ${ }^{3}$ Industrial Engineering Department, Institut Teknologi Sepuluh Nopember, Surabaya, Indonesia \\ e-mail: alhfianzi@gmail.com
}

\begin{abstract}
Designing a fire prevention inspection system in buildings is very necessary, to determine the level of reliability. The fire prevention management system uses the following criteria: precautionary measures and preventive supervision against fire hazards. The assessment of the system design is carried out by means of a questionnaire for respondents who understand / are experts in fire problems, and the application of the system design uses direct surveys and questionnaires to the building manager. The assessment is carried out at the smallest level. Analysis of the building reliability inspection system in fire prevention using the Analytical Hierarchy Process (AHP) method, the criteria used are: prevention, limitation and extinguishing against fire. The fire prevention management system uses the following criteria: precautionary measures and preventive supervision against fire hazards. The results of the reliability inspection of the Ki Hadjar Dewantara Mako Kodiklatal building in Surabaya with a value of 94.06\% indicated that the reliability system was in the "Less Reliable" category for fire hazard prevention.
\end{abstract}

Keywords: Inspection, fire prevention, reliability.

\section{INTRODUCTION}

Building construction requires developers and building owners to pay attention to safety aspects, one of which is fire safety. A fire incident has occurred in a building owned by the Indonesian Navy, the last incident in 2020 was a fire at the Headquarters building. Research on the reliability system of the Indonesian Navy building for fire prevention has never been carried out until now. The Indonesian Navy has many buildings which on average have been established for more than 10 years, from several buildings in the Indonesian Navy, including the building at the Indonesian Naval Education Institute in the Surabaya area, namely the $\mathrm{Ki}$ Hadjar Dewantara Doctrine Command building. and the Indonesian Navy Training and Education (Kodiklatal), where many of the main officials have offices inside the building. In the building there are also many military activities both in terms of administration and important items or archives, this is the basis for research on fire to ensure safety and disaster prevention for the building itself and its contents.
In multi-storey buildings there is a high risk of fire hazard, therefore a reliable fire protection system is needed. A reliable fire protection system is a means of fire prevention. For fire prevention, the Ki Hadjar Dewantara Mako Kodiklatal Building is equipped with a reliable fire protection system. To find out the existing protection system in the $\mathrm{Ki}$ Hadjar Dewantara Mako Kodiklatal Building, further research is needed. This research refers to the "Regulation of the Minister of Public Works Number 26 of 2008.

To determine the weighting of buildings, one method that is widely used is the Analytic Hierarchy Process (AHP) method developed by Thomas L. Saaty. AHP is a theory of measurement through pairwise comparisons and relies on expert judgment to obtain weighting. Decision making in the AHP method that needs to be known is the problems, needs and objectives of the decision, decision criteria, sub-criteria, stakeholders, affected groups and alternatives taken.

Central office buildings are generally built vertically, so that in the event of a fire it 
will cause the fire to develop rapidly and have a high heat release value, besides that, the interior arrangement of the space / seating layout and the exit that does not meet the exit requirements will interfere with the evacuation process. To provide safety and mental safety from fire hazards, it is necessary to comply with fire evacuation system design standards in the form of fire doors, fire ladders, temporary rescue rooms and escape routes. Assessment of building safety against fire hazards based on SNI standards and Kepmen PU using the AHP method by comparing parts of the active protection system, passive protection system, means of evacuation and fire extinguisher access and fire safety management. Each system is weighted.

\section{LITERATURE REVIEW}

\subsection{Reliability}

The definition of reliability according to Kapur and Lamberson is "the probability that when the operation is in certain environmental conditions, the system will show its ability to match the expected function within a certain time interval". Reliability is a probability that is always associated with the accumulated time over which a tool operates without experiencing damage under certain environmental conditions. Damage occurs when the tool does not function as intended. The definition of reliability is a clear criterion for determining damage to a system, that is, if the system does not function as it should.

\section{$2.2 \quad$ Building Reliability}

A building is a physical form of the result of a construction work integrated with its domicile, partly or wholly above and / or in land and / or water, which functions as a place for humans to carry out activities, whether for shelter or residence, religious activities, business activities, social activities, culture, and special activities. To carry out the functions and uses of buildings that have complementary features, either directly or indirectly, these facilities are divided into mutually supporting systems for the smoothness and comfort of the building. Building is a system; the system is defined as an arrangement of parts that are interconnected or dependent on one another that form a complex unit and apply to one function.

Building reliability is the level of perfection in the condition of protective equipment that ensures the safety, function and comfort of a building and its environment during the life of the building. Reliability requirements include requirements for safety, health, comfort and convenience which are determined based on the function of the building. Meanwhile, building safety requirements include the building capacity requirements to support load loads, as well as the building's ability to prevent and cope with fire and lightning hazards.

\subsection{Fire Hazard}

A fire occurs when a chain reaction occurs between combustible materials (fuel), oxygen and heat (heat) which is often called the fire triangle. When this process occurs in a residential unit, the heat will continue to increase, if sufficient fuel is available and oxygen continues to flow until the temperature reaches the flashover point, which is when the temperature of the hot gas layer in the room exceeds $500 \circ \mathrm{C}$ and the heat flux to the floor exceeding $20 \mathrm{KW} / \mathrm{m} 2$. Furthermore, the fire process is increasingly becoming with the burning of household furniture and building elements in the residential unit either by convection, induction or radiation.

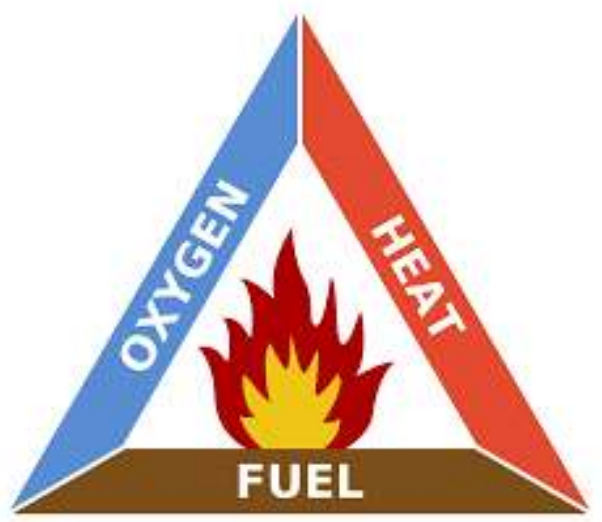

Figure 1. Triangle of Fire

There are four things that need to be considered in relation to the danger of fire, namely: occupants (humans), the contents of the building (property), the structure of buildings and buildings that are located close to the burning building. While the fire hazard includes two things, namely: thermal (temperature and flame) and non-thermal (smoke and poisonous gases). The main danger to humans is smoke poisoning, about $75 \%$ of deaths in building fires (tall buildings) are due to this, while $25 \%$ of deaths are caused by high temperatures in the building.

\subsection{Fire Prevention in Buildings}

All buildings other than houses must be equipped with passive and active protection systems. Fire regulations also exist on Safeguarding against Fire Hazards in Buildings 
and the Environment, as well as on Urban Fire Management.

Prevention of fire hazards in buildings and the environment is all efforts related to the technical provisions and requirements needed in regulating and controlling the implementation of building construction, including in the framework of the licensing process, implementation and utilization / maintenance of buildings, as well as inspection of the feasibility and reliability of the building against fire hazard.

\subsection{Analytical Hierarchy Process (AHP) concept}

The Analytic Hierarchy Process (AHP) is a theory developed by Thomas Saaty for measuring intangible factors through paired comparisons using judgments from a 1 to 9 fundamental scale and resulting in priorities for the factors. It can be applied to both tangibles and intangibles and is used for decision making by structuring a hierarchical model with a goal, criteria (sub-criteria), and alternatives then making pairwise comparison judgments about the dominance of groups of elements in a level below with respect to the element from which they are connected in the level above. In the end the priorities of all the elements are synthesized to rank the alternatives. These simple hierarchies can be extended to multilevel decision models with hierarchies of benefits, opportunities, costs and risks.

The AHP has been applied in many areas including resource allocation and conflict resolution. There are numerous intangibles that have great impact that we must first measure before we can include them as variables. What is most significant is that intangibles can only be measured through expert judgment and only relative to the goals of concern in a particular situation. In this study, AHP is used to measure the intensity or weight of each main aspect of each technology component by analyzing using pairwise comparisons of each criteria.

\section{RESULT AND DISCUSSIONS}

\subsection{Analysis of the Reliability of the Building Safety System (KSKB)}

Assessment of Building Security System Components (KSKB) against fire hazards in the Ki Hadjar Dewantara Kodiklatal building was carried out using 2 methods, namely the Analytical Hierarchy Process (AHP) method and the checklist method based on the Regulation of the Minister of Public Works No. 26 of 2008. Components of fire protection systems in buildings: site equipment, rescue facilities, passive protection systems, and active protection systems.

3.2 Reliability System Analysis with variable fire prevention and management systems using the Analytical Hierarchy Process (AHP) Method.

The paired comparison components with the fire prevention reference are then assessed in the form of a matrix as follows:

\section{a. Fire Prevention Weight Criteria}

Calculate the eigenvalues of the vector by multiplying the matrix elements in a row and the power of $\mathrm{n}$ as shown in the formula below:

$$
\begin{aligned}
& W i=(1,000 \times 0,200)^{1 / 2}=0,447 \\
& W i=(5,000 \times 1,000)^{1 / 2}=2,236 \\
& \mathrm{Wi}=2,683 \\
& W i=\sqrt[n]{a 11 \times a 12 \times \ldots \ldots \ldots a 1 n}
\end{aligned}
$$

Calculate the normalized eigenvectors for each component, with the following formula:

$$
\begin{aligned}
X i & =\frac{w i}{\sum w i} \\
W i & =(1,00 \times 1,00 \times 1,00)^{1 / 3}=1,000 \\
W i & =(1,00 \times 1,00 \times 1,00)^{1 / 3}=1,000 \\
W i & =(1,00 \times 1,00 \times 1,00)^{1 / 3}=1,000 \\
W i & =3,000
\end{aligned}
$$

Calculate the max Lamda with the following equation:

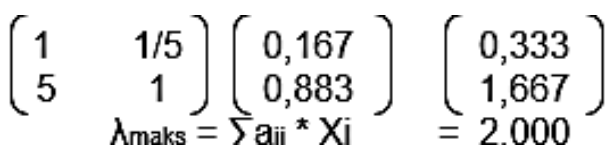

Perform a consistency test with the following equation:

$$
\begin{aligned}
& \mathrm{Cl}=(\text { Amaks }-\mathrm{n}) /(\mathrm{n}-1) \\
& \mathrm{Cl}=(2,000-2) /(2-1)=0.000
\end{aligned}
$$

With the size of the matrix $\mathrm{n}=2$ from the $R I$ table, the value of $R I=0.00$ is obtained, so that the $C R$ value can be calculated by using Equation 2.8:

$$
\begin{aligned}
& \mathrm{CR}=\mathrm{Cl} / \mathrm{RI} \\
& \mathrm{CR}=0.000 / 0.00=0.000
\end{aligned}
$$

The terms of the comparison matrix can be accepted if the $C R$ value is $<0.1$, so the results of the above assessment are acceptable $\mathrm{CR}=$ $0,000<0.1$ (Ok). 
b. Perform the steps above according to the weight of the following criteria, namely fire restrictions and fire suppression.

c. Repeat the above calculations according to the number of respondents.

d. Then do the weighting against the criteria.

1) Weighting criteria comparison matrix. Then Calculate the eigenvalues of the vector by multiplying the matrix elements in a row and the power of $\mathrm{n}$ as shown in the formula below: $W_{i}=\sqrt[n]{a 11 \times a 12 \times \ldots \ldots \ldots \ldots a 1 n}$

Calculate the normalized eigenvectors for each component, with the following formula:

$$
X \dot{i}=\frac{w i}{\Sigma w i}
$$

Calculate the max Lamda with the following equation:

$$
\begin{aligned}
& \left(\begin{array}{lll}
1.000 & 1.000 & 1.000 \\
1.000 & 1.000 & 1.000 \\
1.000 & 1.000 & 1.000
\end{array}\right)\left(\begin{array}{l}
0.333 \\
0.333 \\
0.333
\end{array}\right)\left(\begin{array}{l}
1.000 \\
1.000 \\
1.000
\end{array}\right) \\
& \lambda_{\text {maks }}=\sum \mathrm{aij}^{\star}{ }^{\star} \mathrm{Xi}=3.000
\end{aligned}
$$
equation:

Consistency test with the following

$$
\begin{aligned}
& \mathrm{Cl}=(\lambda \text { maks }-\mathrm{n}) /(\mathrm{n}-1) \\
& \mathrm{Cl}=(3,000-3) /(3-1)=0,000
\end{aligned}
$$

With the size of the matrix $\mathrm{n}=3$ from the $\mathrm{RI}$ table, the value of $\mathrm{RI}=0.58$ is obtained, so that the $C R$ value can be calculated.

$$
\begin{aligned}
W i & =(1,00 \times 3,00 \times 3,00 \times 7,00)^{1 / 4}=2,817 \\
W i & =(0,33 \times 1,00 \times 1,00 \times 5,00)^{1 / 4}=1,136 \\
W i & =(0,33 \times 1,00 \times 1,00 \times 3,00)^{1 / 4}=1,000 \\
W i & =(0,14 \times 0,20 \times 0,33 \times 1,00)^{1 / 4}=0,312 \\
\hline W i=5,266 & \\
C R & =C l / R I \\
C R & =0.000 / 0.58=0.000
\end{aligned}
$$

The terms of the comparison matrix can be accepted if the $C R$ value is $<0.1$, so the results of the above assessment are acceptable $\mathrm{CR}=0,000<0.1$ (Ok).

\subsection{Fire Prevention Management System Weighting Analysis}

a. The calculation of the consistency test against the weight of the criteria for action and supervision.

Table 1. Comparison Matrix Table

\begin{tabular}{c|c|c|c|c} 
CRITERIA & PM\&PH & PB\&PT & RKD & PKR \\
\hline PM\&PH & 1.000 & 3.000 & 3.000 & 7.000 \\
\hline PB\&PT & 0.333 & 1.000 & 1.000 & 5.000 \\
\hline RKD & 0.333 & 1.000 & 1.000 & 3.000 \\
\hline PKR & 0.142 & 0.200 & 0.333 & 1.000
\end{tabular}

In formulating a strategy using the SWOT method. The first step is to analyze Internal and External factors in warship Mechanical Engineering Study Program are continued with the grouping of these factors into elements Strength, Weakness, Opportunity and Threat. Then weighting of these factors is carried out to get the chosen strategy.

Calculate the eigenvalues of the vector by multiplying the matrix elements in a row and the power of $\mathrm{n}$ as shown in the formula below: $W_{i}=\sqrt[n]{a 11 \times a 12 \times \ldots \ldots \ldots a 1 n}$

$$
\text { Calculate the normalized }
$$
eigenvectors for each component, with the following formula:

$$
X \dot{i}=\frac{w i}{\Sigma w i}
$$

Calculate the max Lamda with the following equation:

$$
\begin{aligned}
& \left(\begin{array}{llll}
1.000 & 3.000 & 3.000 & 7.000 \\
0.333 & 1.000 & 1.000 & 5.000 \\
0.333 & 1.000 & 1.000 & 3.000 \\
0.142 & 0.200 & 0.333 & 1.000
\end{array}\right)\left(\begin{array}{l}
0.535 \\
0.216 \\
0.190 \\
0.059
\end{array}\right)\left(\begin{array}{l}
2.167 \\
0.881 \\
0.762 \\
0.242
\end{array}\right) \\
& \lambda_{\text {maks }}=\sum \mathrm{aij}^{*}{ }^{*} \mathrm{Xi}=4.052
\end{aligned}
$$




\section{CONCLUSION}

\subsection{Conclusions}

a. The conclusions that can be drawn regarding the analysis of the fire prevention inspection system and its application based on the description of data processing are as follows:

a. The steps for the building reliability inspection system in preventing fire hazards using the AHP (Analitycal Hierarchy Process) method are made from the PU Balitbang, 2005. The results of the questionnaire were filled in by 6 (people) who are experts in the field of fire protection and prevention

b. management and a weighting process has been carried out so that a building safety system reliability design can be made in the form of a Fire Hazard Reliability Checklist Sheet, which can be used to assess and inspect buildings for preventive measures against fire hazards in buildings.

c. The application of the Fire Prevention System and Fire Prevention Management in determining the reliability level of the Building Safety System can be seen from the weight obtained, namely $59 \%$ for the Fire Prevention System and $41 \%$ in the Fire Prevention Management. Of the two systems the Fire Prevention System has a greater weight than the Prevention Management system, however, both of them are related in assessing the reliability of the building safety system by meeting the requirements according to the standard rules of the Balitbang PU, 2005.

d. Reliability checks that have been carried out by the building management and researchers in accordance with the conditions in the field show that the reliability value of the Ki Hadjar Dewantara Mako Kodiklatal building is $94.06 \%$, and is in the LESS ANDAL category. According to the rules of Balitbang PU, the Limit on the Level of Reliability is Less Reliable, namely $75 \%<94.06 \%<95 \%$.

\subsection{Suggestions.}

Based on the conclusions of the research that the author has carried out; the authors can provide the following suggestions:

a. The results of the user The Management of the Kodiklatal Mako Building must carry out several recommendations from observations and assessments in the field so that the reliability system of the Ki Hadjar Dewantara building becomes the "ANDAL" category. The following table contains several recommendations that must be implemented:

b. The Mako Kodiklatal Building Manager can re-weigh the fire prevention system in buildings for the sake of perfect building reliability systems.

c. To use a reliability check system in fire prevention, it requires experts at the Kodiklatal Center who know the fields of fire prevention management and fire protection in buildings.

d. The existing Building Safety System Reliability Check System can be used as a reference to check the reliability of other buildings in the Kodiklatal Center.

\section{ACKNOWLEDGEMENT}

The authors greatly acknowledge the support from Naval Technology College, STTAL Surabaya Indonesia for providing the necessary resources to carry out this research work. The authors are also grateful to the anonymous reviewers and journal editorial board for their many insightful comments, which have significantly improved this article.

\section{REFERENCES}

Adiwidjaya, Roy, 2012. Study of the Reliability Level of Fire Protection Systems in Apartment Buildings (Case Study of Apartments in Surabaya). Journal of Architecture and Built Environment Vol 39 No 1, 2012.

Arda Dwi Cahyo Ruspianof, 2017. Title of Reliability Evaluation of Fire Protection Systems in Buildings (PLN Riau and Riau Islands Buildings). Journal of Scientists, Volume 17, Number 2, October 2017, 39-45.

Dheva Vegar Anggara, 2012. Evaluation of Fire Safety Reliability in Fisip II Unbraw Malang Building. Department of Civil Engineering, Faculty of Engineering, University of Brawijaya Malang.

Diharto and Ristya Mulia Nugroho, 2012. Reliability Evaluation of Unnes Rusunawa Buildings in terms of the Perceptions of Students Who Live It. Journal of Civil Engineering and Planning No 01 Vol 14, January 2012, Pages 51-60.

Gunawan Tri, 2011. Building Reliability Inspection System in Fire Hazard Prevention Case Study of Solo Square Shopping Center Building. Surakarta. Sebelas Maret University. 
Hendrina Mandey, PAT Kawatu, VD Doda, 2017. Reliability Analysis of Building Fire Safety Systems Using Pd-T-112005-C at FKM Unsrat Manado, Journal of the Faculty of Public Health, Sam Ratulangi University, Manado.

Inseun Yuri Salena, Meylis Safriani, Novriza, 2019. Identification of Fire Protection Systems and Reliability Levels of Building Safety, Faculty of Public Health at Teuku Umar University. Journal of Building and Civil Engineering Education, Vol 5, No 2, December 2019.

Jatiaryo Sidiq Ramadhan, Moch Amron, Gina Bachtiar, 2016. Evaluation of Maintenance Implementation of Building Reliability (Case Study in Rusunawa Pulogebang, Jakarta). Journal of Technical and Vocational Education, Vol 2, Number 2, December 2016.

Juwana, Jimmy 2002. High Building System Guide. Jakarta: Erlangga.

Kadarsyah Suryadi, 2010. Decision Support System A Structural Discourse Idealization and Implementation of Decision-Making Concept, PT. Youth Rosdakarya, Bandung.

Decree of the Minister of Public Works Number 10 / KPTS / 2000, Concerning Technical Provisions for Safeguarding Against Fire Hazards in Buildings and the Environment.

Decree of the Minister of Public Works Number 11 / KPTS / 2000, Concerning Technical Provisions for the Management of Fire Management in Cities.

M Heri Zulfiar, Akhid Gunawan, 2018. Evaluation of the Fire Protection System in the 5-Floor UNY Hotel Building in Yogyakarta. Journal of Semesta Teknika Vol 21 No 1, 2018.

Regulation of the Minister of Public Works No. 26 of 2008 concerning Technical Requirements for Safeguards Against Fire Hazards in Buildings and the Environment,

Kasal Regulation Number Perkasal / 81 / XII / 2010 dated December 13, 2010 concerning Administrative Guidelines for the Implementation of the Material Worthiness of the Indonesian Navy (PUM-7.01).

PD-T-11-2005-C Regarding Building Fire Safety Inspection.

Rangga Pratama, Rian Trikomara, 2017. Reliability Analysis of Building Safety Systems Against Fire Hazards. FTEKNIK Journal Volume 4, No 2, October 2017.

Saaty, Thomas L. 1993. Decision Making for Leaders. PT. Pustaka Binaman Pressindo, Jakarta.

SNI 03-1736-2000. Passive Protection Planning Procedures for Prevention of Fire Hazards in Houses and Buildings,

Theresia Hindarti G. ultom, 2018. Safety System Reliability Analysis Building as Fire Protection in Central Java Police Building. Journal of Public Health (EJournal) Volume 6, Number 5, October 2018.

Tundono, 2008. Fire Prevention in Dense Settlements in Krendang Village, Tambora District, West Jakarta, November 2019, Indonesian Society Abdi Journal.

Yervi Hesna, Benny Hidayat, Satria Suwanda, 2009. Evaluation of the Application of the Fire Safety System in Dr. M Jamil Padang, Journal of Civil Engineering Volume 5 No 2, Oct 2009. 